\title{
Kebijakan Luar Negeri Sebagai Manifestasi Eksistensi Negara
}

\section{Wibi Hambalie}

Mahasiswa Jurusan Hubungan Internasional, Fakultas IImu Sosial dan IImu Politik, Universitas Katolik Parahyangan

\begin{abstract}
Abstrak
International relation can not be separated from state as the main actor. It is common for state to gain interest as much as it needs. Foreign policy becomes a way to communicate with another state. The state can use their foreign policy not only to communicate but also to show their manifestation and existance in the international system. Before producing a foreign policy, a state might want to prepare themselves in order to create a suitable policy for their people. Several factors like geographical position and demography or military strengh might influence the foreign policy. A decent foreign policy should reflect the will of the people. Foreign policy in the other way as a proof of existence could use a tool to deal with others.

Keywords: state, foreign policy, manifestation, existance.
\end{abstract}

\section{Pendahuluan}

Negara merupakan bentuk kesadaran kolektif masyarakat. Masyarakat yang merupakan salah satu komponen utama penyusun negara, akanmenjadi fokus penulisan ini. Negara dapat diinterpretasikan sebagai alat bagi masyarakat untuk melakukan hubungan diplomatik dengan negara lainnya. Masyarakat dan sudut pandangnya terhadap suatu fenomena internasional dapat dicerminkan melalui keputusan atau kebijakan yang dikeluarkan oleh pemerintah. Opini publik yang terbentuk atas suatu fenomena cepat atau lambat harus ditampung oleh pemerintah. Bahaya yang laten mengintai ketika pemerintah tidak menampung opini publik pernah terjadi pada sejumlah negara. Perubahan gaya pemerintahan menuju pemerintahan yang berdemokrasi menyebabkan peran masyarakat dalam negara menjadi sangat vital. Hal tersebut menjadi sangat vital karena negara yang terlalu memaksakan kehendak penguasa dan menekan rakyat terlalu lama dapat berujung pada kudeta. Perubahan adalah hal yang sah untuk dilakukan oleh pemimpin, namun perlu kepekaan terhadap opini publik untuk mencegah konflik dan kudeta.

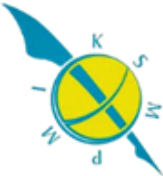


Negara yang merupakan sebuah kesadaran kolektif yang kelak mengarah menjadi fungsional secara sistemik akan mengalami proses "pendewasaan". Kesadaran kolektif membawa individu dengan lainnya bersatu dibawah sebuah negara. Negara yang kuat didasari dari sebuah kesadaran kolektif tentang pentingnya persatuan dibawah naungan negara yang mereka impikan. Hingga detik ini kesadaran kolektif dapat memainkan peranan sebagai pemersatu, atau pemecah keutuhan.

Sejumlah pemberontakan didasari rasa ketidakpuasan terhadap pemerintahan yang sedang memimpin seringkali berasal dari kebencian segelintir orang saja yang lambat laun menyebar. Pemerintah yang berdaulat mampu mengatasi konflik yang timbul akibat perbedaan opini atau yang mendasar pada perbedaan tentang kesadaran kolektif. Hal yang menjadi pertanyaan besar adalah bagaimanakah mengatasi perbedaan akibat kesadaran kolektif yang variatif pada tingkat global? Kontrol tentu menjadi suatu hal yang tidak mungkin dan irasional mengingat sistem yang dianut oleh dunia saat ini adalah anarki.

Struktur dunia yang anarki membuat negara dapat bergerak dengan bebas untuk mendapatkan kepentingannya Kebebasan yang dimaksudkan adalah kebebasan secara tersirat dalam arti kebebasan tetap ada namun untuk mendapatkannya dibutuhkan upaya tertentu. Bebas dalam hal ini dapat dimiliki oleh setiap negara yang mampu memanfaatkan celah dalam sistem yang anarki ini. Dalam sistem yang anarki ini bukan tidak diakui tentang hukum internasional atau konvensi internasional yang mengikat negara yang berpartisipasi didalamnya. Berlakunya pacta sunt servanda menjadikan hukum internasional itu sendiri sebagai celah bagi negara untuk mendapatkan kepentingannya.

Negara dapat mengatur bagaimana ia bekerja dan bersikap mampu mengendalikan negara lain. Hal yang saat ini adalah bagaimana membedakan motif lahirnya sebuah kebijakan luar negeri.

\section{Bagaimana negara menunjukan manifestasi dan menggunakan kebijakan luar negeri sebagai wujud eksistensinya?}

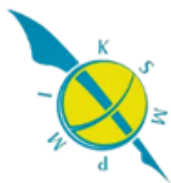


Dalam penulisan kali ini penulis akan mencoba memberikan penggambaran tentang negara melalui ideal dari Plato. Negara yang ideal setidaknya memiliki masyarakat madani dan berkompetensi. Selain masyarakat, negara juga membutuhkan pemimpin yang peka terhadap segala kebutuhan negara. Kedua hal tersebut dibutuhkan oleh negara, terlebih saat ingin menjlain komunikasi dengan negara lain. Jika sebuah negara melakukan hubungan dengan negara lain sebelum mencapai tahap ideal, maka kemungkinan besar hubungan tersebut akan menguntungkan satu pihak saja. Penulisan kali ini akan membahas tentang negara bermanifestasi dalam kebijakan luar negeri dan pemenuhan kebutuhan akan eksistensi melalui kebijakan luar negeri.

\section{Kebijakan luar negeri sebagai manifestasi}

kebijakan luar negeri dapat mencerminkan seberapa kuat suatu negara. Kapasitas kekuatan negara tidak hanya terbatas pada militer saja tetapi pada modern ini menyangkut pula tentang demografi hingga kualitas sumber daya manusia. Perbedaan mencolok tentu terjadi ketika ada kepentingan yang berbenturan antara negara yang kuat dan yang lemah secara politik.

Struktur kekuatan negara yang tidak lagi terpusat pada kekuatan militer semata mendorong negara untuk memperbaiki sektor lainnya yang berkaitan dengan masyarakat. Hal

ini sejalan dengan idealisme Plato dimana sebuah negara harus memiliki masyarakat yang berada di tahap profesional. ${ }^{1}$ Kondisi masyarakat yang teredukasi secara baik dan memiliki kemampuan penguasaan teknologi akan mendorong negara memiliki output yang lebih baik. Masyarakat yang berpendidikan juga akan secara perlahan mempengaruhi kekuatan negara. Negara dengan kualitas pendidikan yang rendah akan membutuhkan waktu yang lebih lama pula untuk menjadi negara maju. ${ }^{2}$ Beberapa negara dunia ketiga menjadi bukti betapa pentingnya pendidikan dalam

\footnotetext{
${ }^{1}$ Plato. Plato: Republik. (Jakarta: Narasi, 2015), 27

2 Plato. Plato: Republik. (Jakarta: Narasi, 2015), 86-87
} 
mendirikan sebuah negara yang kuat. Kerjasama dan transfer teknologi dari negara dunia pertama ke dunia ketiga tidak terbukti berjalan sesuai harapan. Sejumlah negara menjadi kuat dalam sistem internasional berkat kemampuan menguasai teknologi dan memiliki pendidikan yang cukup. Teknologi dalam era modern ini juga memiliki peranan penting dimana teknologi dapat berfungsi sebagai alat tawar dalam negosiasi.

Negara dengan demografi yang besar dan wilayah yang luas dapat menjadi faktor pendorong negara memiliki dampak yang besar dalam sistem internasional. Indonesia dan China sebagai negara yang memiliki bonus demografi dan teritori yang luas dalam sejumlah kasus memiliki peranan yang vital. ${ }^{3}$ Indonesia dalam ASEAN memiliki peranan penting dan kekuatan yang lebih jika dibandingkan dengan Laos. Kekuatan Indonesia diwujudkan dalam bentuk kebijakan luar negeri terkait ASEAN. Salah satu contohnya adalah ketika Indonesia memberlakukan halangan non-tarif bagi negara anggota ASEAN. ${ }^{4}$ Pihak yang merasa terancam bukanlah Indonesia, tetapi anggota ASEAN lainnya yang cukup bergantung pada impor Indonesia atas produk mereka, seperti Thailand dengan ekspor beras ke Indonesia. Kebijakan luar negeri Indonesia yang berkaitan dengan ASEAN mungkin akan lebih tinggi prioritasnya dibandingkan dengan Laos atau Kamboja sekalipun ASEAN menganut sistem unilateral.

Negara-negara maju tentu memiliki posisi tawar yang lebih tinggi dalam sistem internasional dibandingkan dengan negara berkembang. Kebijakan luar negeri pun dapat dibuat untuk mengikuti sebuah sistem yang berlaku. Nyatanya, negara berkembang terkadang masih harus melakukan bandwagoning dengan negara maju untuk mengembangkan dirinya sendiri. Sebagai contoh, negara-negara kepulauan di pasifik akan sangat dekat dengan Australia secara politik.

\footnotetext{
${ }^{3}$ The Economist. Demography: China's Achilles Heel. 2012.

http://www.economist.com/node/21553056 diakses pada 15 April 2017

${ }^{4}$ Pattharapong Rattanasevee. East Asia Forum. Why Indonesia Should Take A Leading Role In ASEAN. 2015. http://www.eastasiaforum.org/2015/03/28/why-indonesia-should-take-aleading-role-in-asean/ diakses pada 28 April 2017
} 
Kebijakan luar negeri suatu negara yang memiliki sejumlah faktor pendukung seperti manajemen sumber daya manusia yang mapan dan memiliki wilayah yang luas dapat berujung membentuk sebuah kebijakan luar negeri yang befungsi sebagai senjata. Pergeseran perang dari perang dalam konteks militer menjadi perang dalam persaingan ekonomi dan teknologi juga semakin menguatkan posisi negara untuk menjadi kuat melalui kebijkan luar negeri mereka. Kebijakan Amerika Serikat untuk menginvasi Irak pada 2003 menjadi sangat sulit dihentikan oleh negara lain. Invasi ke Irak secara mutlak merupakan hak Amerika Serikat sebagai sebuah negara. Kebijakan tersebut mungkin dapat dihentikan jika dilakukan oleh negara yang lemah, tetapi Amerika Serikat merupakan salah satu negara terkuat di dunia baik dari segi militer dan segi ekonomi.

Bagaimana Amerika Serikat memaksimalkan posisi mereka dalam sistem internasional menunjukan penggunaan kebijakan luar negeri sebagai alat untuk mendapatkan kepentingan mereka dan masih adanya lubang dalam organisasi internasional sebagai media pencegah perang. Negara lain dapat menunjukan respon atas invasi tersebut, tetapi pada akhirnya tidak diwujudkan dalam bentuk kebijakan luar negeri yang riil dan menekan Amerika Serikat secara hebat.

Sebagai sebuah bentuk kesadaran kolektif, negara secara langsung harus menopang kebutuhannya dengan segala cara yang diperlukan. ${ }^{5}$ Upaya-upaya pemenuhan kebutuhan ini dilakukan oleh setiap negara untuk mempertahankan dirinya. Kompleksitas menjadi meningkat ketika upaya satu negara bersinggungan atau bertolakbelakang dengan upaya negara lain. Upaya negara dapat dilakukan dengan kebijakan luar negeri. Fungsi kebijakan luar negeri sebagai sebuah media komunikasi menjadi sangat nampak pada kondisi seperti ini.

Kebijakan luar negeri sebagai manifestasi dari keinginan masyarakat suatu negara dapat dilihat dari tujuan sebuah kebijakan dan ke arah mana kebijakan tersebut

${ }^{5}$ Plato. Plato: Republik. (Jakarta: Narasi, 2015),273

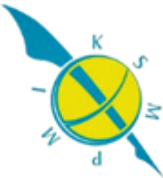


berorientasi. Setiap negara akan memiliki bentuk manifestasi yang berbeda satu dengan lainnya atau dapat pula serupa.

Orientasi pembuatan kebijakan luar negeri dapat dilihat dari kondisi geografis atau faktor kekuatan negara lainnya. Negara yang memiliki komposisi maritim yang lebih mendminasi, seperti Indonesia, akan cenderung memaksimalkan potensi maritimnya dibandingkan dengan sektor darat. Upaya revitalisasi sejumlah pelabuhan dan pemotongan waktu bongkar muat di beberapa pelabuhan di Indonesia setidaknya merupakan upaya dalam menghadapi persaingan dengan negara-negara persinggahan lainnya seperti Singapura. Melihat jauh ke Asia timur, Jepang yang masih negara pasifis dalam militer pun akan menyesuaikan kebutuhannya dalam ha militer melalui kebijakan luar negeri. Jepang lebih memanfaatkan sektor ekonominya untuk menganntikan kelemahannya dalam sektor militer. Bukti nyata dari Jepang adalah ia termasuk dalam sepuluh donor terbesar dalam pembiayaan pasukan perdamaian PBB.

Manifestasi dapat mencerminkan kondisi negara dan menunjukan apa keinginan dari negara tersebut. Sebuah kebijakan yang terkesan domestik dapat berubah menjadi kebijakan luar negeri. Manifestasi dapat mencerminkan sikap negara, apakah ia bertahan ataukah ia menyerang. Pada umumnya kebijakan luar negeri seolah berada pada zona abu-abu, dimana sangat sulit dibedakan sikapnya, bertahan atau menyerang. Hal ini mungkin juga disebabkan manifestasi sendiri masihlah rancu dalam arti, manifestasi satu individu akan sangat jelas, tetapi manifestasi dari sebuah kumpulan individu yang terikat hanya dengan kesadaran kolektif akan sangat sulit dibedakan. Hal tersebut terjadi karena pada sistem demokrasi atau pun sistem pemerintahan lainnya terdapat sejumlah individu yang memegang kekuasaan lebih atas sistem yang dianut. Secara mikro, subjektivitas menyebabkan perbedaan antar individu. Secara makro, sebuah sistem harus menggeneralisir seluruh keinginan dalam satu hasil. Manifestasi tidak hanya berbicara tentang tindakan, tetapi juga sikap dan terkadang perasaan. Manifestasi perasaan mungkin menjadi yang paling abu-abu. Layaknya tindakan seorang

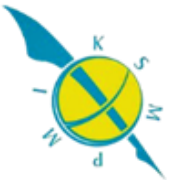


memukul lainnya, bisa disebabkan oleh setidaknya dua perasaan takut dan marah. Bagaimana kita dapat menegtahui apakah ia memukul karena merasa takut atau karena marah? Lebih jauh lagi, apakah ia memukul sebagai pembelaan diri atau sebagai pencegahan suapaya ia tidak dipukuli di masa mendatang? Semua pertanyaan itu hanya bisa diajawab oleh dirinya. Hal ini juga yang terjadi pada negara, keputusan dibuat oleh negara sebagai manifestasi dan bertujuan untuk menyerang atau bertahan, pihak asing dapat menilai, tetapi sebenarnya negarabersifat layaknya kotak hitam. Semua kebenaran hanya diketahui oleh pihak-pihak pembuat kebijakan saja.

Thailand yang sedang merencanakan membangun kanal untuk mempersingkat waktu ekspedisi dari sekitar asia tenggara yang mana pada kondisi normal ekspedisi barang harus melewati Indonesia dan Singapura. ${ }^{6}$ Motif Thailand terlihat jelas, motif ekonomi. Jika Kanal Kra beroperasi secar optimal maka berapa kapal yang akan melewati kanal tersebut? Tentu jumlahnya tidak sedikit. Secara kebijakan, pembuatan Kanal Kra merupakan kebijakan yang sangat baik bagi Thailand dan mungkin juga bagi pengguna kapal laut. ${ }^{7}$ Jika rute yang ditempuh semakin singkat, maka itu berarti ada biaya operasi yang dapat dihemat dan akan berujung profit yang lebih optimal. Namun secara regional, kebijakan Thailand ini mengancam setidaknya dua negara, yaitu Indonesia dan Singapura. Opini yang beredar saat ini adalah Thailand seolah "berkhianat" pada Singapura dan Indonesia, karena apa yang dilakukan oleh Thailand berpotensi mengurangi pendapatan kedua negara tersebut. Menjadi sangat mungkin apa yang dilakukan Thailand adalah manifastasi dalam bentuk tindakan untuk menjawab "tantangan" dari Singapura yang selama ini maju berkat posisi dan sistem bongkar muat yang unggul dan "tantangan" dari Indonesia yang sedang memperbaiki sistem bongkar muatnya dan keadaan geografis secara maritim yang masif. Melihat ke dalam masyarakat Thailand, sungai

\footnotetext{
${ }^{6}$ Antara News. Mendedah Ketidakmungkinan Kanal Kra. 2016.

http://www.antaranews.com/berita/600191/mendedah-ketidakmungkinan-kanal-kra diakses pada 15 April 2017.

${ }^{7}$ Lee Yong Leng. Southeast Asia: Essays In Political Geography. ( Singapore: NUS Press, 1986), 103
} 
ISSN 0216-5031

$\mathrm{H}$ a I a m a n | $\mathbf{5 4}$

dan jalur transportasi air telah menjadi bagian hidup mereka sejak lama. Berangkat dari hal tersebut, pemerintah Thailand mengetahui apa kekuatan masyarakat Thailand yang belum terlihat dan pembangunan kanal pun dijalankan untuk memaksimalisasi potensi masyarakat Thailand.

\section{Kebijakan luar negeri sebagai pemenuhan eksistensi negara}

Kebijakan luar negeri juga bertujuan untuk menunjukan eksistensi mereka dalam sistem internasional. Eksistensi pada tingkatan yang tinggi dapat menggentarkan negara lain hanya dengan mendengar nama atau rumor tentang kehadiran negara kuat dalam suatu konflik. Pada era perang dingin setidaknya hal ini benar terjadi. Negara-negara kecil yang telah berafiliasi dengan USSR atau Amerika Serikat akan memiliki konsep deterence. Dalam era perang dingin, deterence menjadi sangat kuat dengan adanya ancaman perang nuklir. Pada kondisi seperti inilah konsepsi tentang kebijakan luar negeri menjadi bukti eksistensi antar negara. Ketika Amerika Serikat memiliki senjata nuklir dan begitu pula dengan USSR, keduanya ingin memperlihatkan bahwa masing-masing memiliki teknologi nuklir. Kepemilikan nuklir pada kala itu menjadi sebuah penentu yang sangat vital. Kebijakan luar negeri negara yang berkonflik dan tidak memiliki konflik pun akan menyesuaikan dengan keadaan. Bagi negara yang memiliki nuklir tentu akan membuat kebijakan luar negeri yang menunjukan bahwa mereka lebih unggul dari kompetitor lainnya

Eksistensi dapat dipahami sebagai sebuah status yang diberikan oleh pihak lain terhadap individu atau dalam hal ini, negara. Berbicara tentang eksistensi mungkin kita tidak akan dapat lepas dari konsep "corgito ergo sum". Negara menggunakan kebijakan luar negeri sebagai hasil berpikir dalam perpolitikan mereka. Kebijakan luar negeri menjadi salah satu bentuk penyaluran hasil pemikiran dan kelak digunakan sebagai bukti bahwa mereka ada di dalam sistem internasional dan menjalankan peran yang spesifik atau general. Berkaitan tentang lemah atau kuatnya eksistensi akan sangat bergantung pada siapa yang memberikan kadar tentang eksistensi itu sendiri. Sebagai contoh jika Amerika Serikat melihat Papua Nugini,

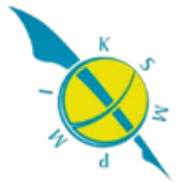


ISSN 0216-5031

$\mathrm{H}$ a I a m a n | $\mathbf{5 5}$

tentu mereka akan melihat bahwa diri mereka superior sebab Papua Nugini pun melihat Amerika Serikat dengan cara demkian. Kebutuhan akan eksistensi menjadi cukup penting dalam hubungan internasional. Eksistensi yang didapatkan baik melalui partisipasi dalam isu tertentu atau yang didapatkan dari kekuatan secara ekonomi dan politik.

Eksistensi meskipun terdengar rancu dan terlalu filosofis secara kenyataannya tetap dibutuhkan bahkan setelah era perang dingin. Layaknya kehidupan sosial dalam skala mikro, kebutuhan akan eksistensi haruslah tercukupi. Tanpa adanya kadar eksistensi yang memadai, maka akan sangat memungkinkan bagi individu untuk terpotong dari lingkungan sosial dan secara tidak langsung akan sulit mendapatkan kebutuhannya. Hal tersebut juga berlaku bagi negara, pengakuan secara de jure dan de facto.memberikan negara eksistensi secara legal, tetapi hanya dengan pengakuan tersebut tidak akan membawa negara mencukupi kebutuhannya. Negara perlu untuk terlibat aktif dalam politik internasional.

Keikutsertaan dalam kegiatan internasional yang telah mejadi agenda politik dan diwujudkan melalui kebijakan luar negeri dapat menjadi alat politik. Kehadiran secara terus menerus akan menimbulkan efek tertentu dan bergantung pada jenis kegiatannya. Seperti apa yang terjadi di Laut Tiongkok Selatan, kehadiran militer dari Tiongkok terbukti cukup efektif untuk mencegah klaim atas Pulau Spartlys. Upaya Amerika Serikat untuk membangun sejumlah pangakalan militer di Australia dan Jepang untuk seolah menahan jalur dagang Tiongkok. Eksistensi tidak hanya ditunjukan melalui militer namun tidak dapat dipungkiri bahwa militer merupakan salah satu cara paling efektif untuk menunjukan pengaruh secara cepat.

Penutup

Kebijakan luar negeri tidak hanya menjadi sebuah hasil pemikiran semata, tetapi juga menjadi perwujudan manifestasi sejumlah unsur dari keadaan suatu negara dan menjadi perwujudan eksistensi. Negara yang terbentuk dari pemikiran kolektif akan memiliki subjektifitas Dalam membentuk sebuah manifestasi, negara memasukan unsur-unsur lokal kedalamnya dan terkadang hal ini yang menjadikan

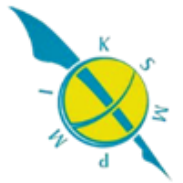


sebuah kebijakan luar negeri suatu negara tidak dapat dimengerti seutuhnya oleh negara lain dan menyebabkan misinterpretasi yang dapat berujung pada konflik. Negara juga membutuhkan eksistensi yang tidak hanya bersumber dari pengakuan legal, tetapi juga membutuhkan keikutsertaan dalam kegiatan internasional.

\section{Daftar Pustaka}

Plato. Republik. Narasi. Jakarta, 2015.

Yong Leng, Lee. Southeast Asia: Essays In Political Geography. Singapore, 1986. NUS Press. Rusdi, Siswanto. Mendedah Ketidakmungkinan Kanal Kra. Antara News. 2016

Rattanasevee, Pattharapong. East Asia Forum. Why Indonesia Should Take A Leading Role In ASEAN. 2015.

The Economist. Demography: China's Achilles Heel. 2012.

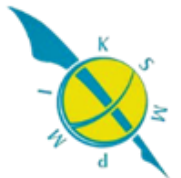

